\title{
A customization-oriented framework for design of sustainable product/service system
}

\author{
Wenyan Song and Tomohiko Sakao \\ Journal Article
}

\section{Tweet}

N.B.: When citing this work, cite the original article.

Original Publication:

Wenyan Song and Tomohiko Sakao, A customization-oriented framework for design of sustainable product/service system, Journal of Cleaner Production, 2016.

http://dx.doi.org/10.1016/j.jclepro.2016.09.111

Copyright: Elsevier

http://www.elsevier.com/

Postprint available at: Linköping University Electronic Press

http://urn.kb.se/resolve?urn=urn:nbn:se:liu:diva-131471

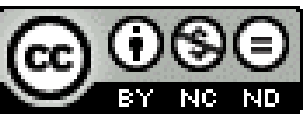




\title{
A Customization-Oriented Framework for Design of Sustainable Product/Service System
}

\author{
Wenyan Song * \\ School of Economics and Management, Beihang University, Beijing 100191, China \\ Email:*198212swy@163.com \\ Tomohiko Sakao \\ Division of Environmental Technology and Management, Department of Management and \\ Engineering, Linköping University, 58183 Linköping, Sweden \\ Email: tomohiko.sakao@liu.se
}

\begin{abstract}
Many manufacturers today are striving to offer high value-added Product/Service System (PSS) due to increasing competition and environmental pressure. PSS design activities face a variety of challenges such as a high level of customization as well as its resulting challenges, i.e., hidden requirements in product use phase, potential conflicts of design attributes, and internal complexity of service processes. However, existing insights for PSS customization are fragmented and insufficient to support manufacturers. Thus, it is necessary to develop a systematic and comprehensive support to solve those issues. In order to support PSS customization in early design phase, this paper proposes a design framework that involves a design process. The proposed design framework is module-based and thus flexible according to the user needs. In addition, it takes advantage of some existing methods. A case study of elevator PSS design shows the feasibility and potentials of the design framework and its associated design process to its broad usage in industry.
\end{abstract}

Key words: Comprehensive Design Framework, Design Conflict Resolving, Modularization, Configuration.

\section{Introduction}

With the increasing competition (Uppenberg and Strauss, 2010), diversification of customer demands (Hu et al., 2011) and environmental pressures (Umeda et al., 2012), many manufacturing companies are striving to re-position themselves as solution providers by offering high value-adding services (Meier et al., 2010). Those manufacturing companies are undergoing a servitization journey towards a tightly-coupled integration of products and services (Beuren et al., 2013, Vandermerwe and Rada, 1988). Servitization can be considered as a process to shift from selling products to selling Product/Service System (PSS) and involves strategic innovation of a company's capabilities (Baines et al., 2007; Vandermerwe and Rada, 1988). PSS is a system consisting of products, services, networks of players and supporting infrastructure, which are jointly capable of fulfilling specific client demands in an economical and sustainable manner (based on (Mont2002, Tukker2004)), which is an important component of servitization. PSS has been heralded as one of the most effective instruments for enhancing resource-efficiency (Tukker, 2015). PSS can also help manufacturers to be differentiated from competitors (Meier et al., 2010).

Early design of PSS is critical to success of PSS design. As compared with physical product 
design, PSS design concerns more about value in use (Meier et al., 2010). Value as such is individual to its recipient (Ulaga and Chacour, 2001), and thus customization in PSS becomes relevant. Effective customization depends on accurate requirements capturing and handling (Jiao and Tseng,2004). However, due to a higher number of and more variable stakeholders involved in PSS, PSS requirements management with the conventional methods for product requirements elicitation is challenged. Moreover, different value propositions to the stakeholders may lead to potential conflicts between design attributes, which is not thoroughly addressed in past PSS design researches (Berkovich et al., 2011, Vasantha et al., 2012). Besides, when customer requirements change in product use phase, it is usually expected to re-arrange service processes and resources, and may even redesign the whole PSS to cope with the changes. This might lead to increase of service response time, as well as cause wasting previous designs. Embedding modularity is effective to avoid this problem, because it brings benefits such as increased feasibility of change, increased variety, and ease of design and testing (Gershenson et al., 2003).Thus, customization involves different steps spanning a wide range of activities from requirements elicitation to module-based configuration, and a systematic and comprehensive support is necessary to achieve effective and efficient PSS customization. However, existing frameworks for PSS design are fragmented and insufficient to support customization, because most of them lack systematic and comprehensive support to specifically guide PSS customization from early requirements identification to design conflict resolving, and to later PSS configuration (Berkovichet al.,2011). This lack of systematic methodical support for the customization process may cause implementation difficulty in practice of PSS customization.

Therefore, this paper proposes a systematic and comprehensive framework with a design process for PSS customization. The design framework consists of four successive design stages. Using merely a set of different methods to effectively design PSS is not necessarily novel, but providing a systematic and comprehensive framework employing specific design process and methods with synergetic effects among them has not been found in previous works. The proposed framework would systematically provide designers with standardized design process reference from the beginning requirements identification to the later concept configuration. Specifically, early conflict resolving mechanism in the framework aims to reduce possible defects in subsequent process of detailed design and delivery. Modularization process and methods of the framework will facilitate frequent design reuse and easier trace-back of failures, and thus enhance design efficiency. The module-based configuration in the framework could help the service provider to achieve flexible PSS customization.

The rest of this paper is organized as follows: Section 2 reviews literature on PSS and PSS design including PSS customization; In Section 3, the framework for PSS customization is formulated, and the associated implementation process is also provided; In Section 4, a case of PSS customization project with an elevator provider is presented to illustrate the feasibility and potentials of the proposed framework. Conclusions and future research suggestions are presented in Section 5.

\section{Literature review}

A brief review of PSS and PSS classification had been conducted (see Section 2.1), and then, the literature addressing customization of PSS was searched for (see Section 2.2). Based on the literature review results in Section 2.1 and Section 2.2, knowledge gaps were identified. 
Although some research efforts have been made in PSS definition, benefits, and classification, there is still a lack of systematic methodical support covering entire design process for PSS customization as shown in Section 2.3.

\subsection{Product/Service System}

PSS has attracted academia and industry based on its economic potentials well as expectation of its environmental superiority (Tukker, 2004). Some review articles have discussed PSS definition, specific features of PSS as well as the benefits and drawbacks, e.g., Beuren et al. (2013). The basics of PSS is not included much here due to the limited space limitation. As opposed to the conventional standardized after-sales service such as spare part provision, PSS offers customized service portfolio to flexibly meet customer's requirements (Kindström and Kowalkowski, 2009). There are different ways of categorization of PSS. Manzini (1999) categorizes PSS into two modes, i.e., use-oriented and result-oriented modes. Roy (2000) further extends the categories to include four modes, i.e., result services, shared utilization services, product-life extension services, and demand side management. Tukker (2004) proposes product-oriented services (e.g., maintenance and repair) adding services to current products, use-oriented services (e.g., product renting, sharing, and pooling) intensifying the use of products, and result-oriented services focusing on customer requirements fulfillment. Among these attempts to categorize PSS, the most widely used is the classification by Tukker (2004), which considers the relationship between the provider and customer and revenue model (Geum and Park, 2011). The paper mainly addresses the first category of PSS, i.e., product-oriented PSS, as many manufacturers seem to work but to face challenges on this type.

\subsection{Customization of PSS}

The literature addressing customization of PSS was searched for. This review consisted of three steps: 1) identified articles describing methods for PSS customization, 2) searched methods potentially useful for PSS customization, and 3) analyzed the methods from the previous two steps. For the first step, keyword search was used. The population to this search consisted of publications written in English as article or review in the Web of Science databases, Scopus, Springer link, and Ebsco. The search conditions applied was that the topic should include "product service system", "functional product", "integrated product service offering (IPSO)", "industrial product service systems (IPS $\left.{ }^{2}\right)$ ", "hybrid solution", "integrated solution", and "servitization"(all as a phrase), combined with the term "customization”. This was followed by content check if each article provides a method (or a framework) for PSS customization. In the second step, journal articles cited by those identified from the first step were mainly targeted. Table 1 shows the keyword search results in different databases. $m / n$ in Table 1 indicates that $n$ articles were found to describe a method in $m$ searched papers. 
Table 1. The keyword search results in different databases.

\begin{tabular}{|lcccc|}
\multicolumn{1}{c}{ Keywords } & $\begin{array}{c}\text { Web of } \\
\text { Science }\end{array}$ & $\begin{array}{c}\text { Springer } \\
\text { link }\end{array}$ & Scopus & Ebsco \\
\hline product service system, customization & $12 / 3$ & $14 / 1$ & $25 / 2$ & $0 / 0$ \\
\hline functional product, customization & $5 / 0$ & $0 / 0$ & $7 / 0$ & $0 / 0$ \\
\hline $\begin{array}{l}\text { integrated product service offering (IPSO) } \\
\text { customization }\end{array}$ & $0 / 0$ & $0 / 0$ & $0 / 0$ & $0 / 0$ \\
\hline $\begin{array}{l}\text { industrial product service systems (IPS }{ }^{2} \text { ) } \\
\text { customization }\end{array}$ & $2 / 0$ & $4 / 0$ & $3 / 0$ & $0 / 0$ \\
\hline hybrid solution, customization & $0 / 0$ & $2 / 0$ & $3 / 0$ & $0 / 0$ \\
\hline integrated solution, customization & $5 / 0$ & $2 / 0$ & $9 / 0$ & $0 / 0$ \\
\hline servitization, customization & $5 / 0$ & $19 / 0$ & $9 / 0$ & $0 / 0$ \\
\hline
\end{tabular}

As a result of the keyword search in the first step, 126 articles were hit as of June $26^{\text {th }}, 2016$. After the content check, only four articles without duplicates were found to describe a customization method. This shows the small amount of the searched insights. In addition, among the four articles, no comprehensive support for PSS customization has been proposed, which is a strong motivation for this research. From the second step,18 articles were found. Table 2 shows outcomes from the 22 articles in total as a result from the third step (the four articles from the first step are marked with ${ }^{*}$ ). The other 18 ones could be potentially useful to achieve the goal of the article. 
Table 2. Outcomes of literature on PSS customization (marked with *) or potentially useful for PSS customization.

\begin{tabular}{|c|c|}
\hline Literature & Outcomes \\
\hline $\begin{array}{l}\text { Song and Sakao } \\
(2016)\end{array}$ & $\begin{array}{l}\text { A method to identify and resolve service design conflicts based on service function } \\
\text { and attributes analysis and TRIZ (theory of inventive problem solving). }\end{array}$ \\
\hline $\begin{array}{l}\text { Nemoto et al. } \\
\text { (2015) }\end{array}$ & $\begin{array}{l}\text { A framework for managing and utilizing design knowledge to support idea } \\
\text { generation in the conceptual design of PSS. }\end{array}$ \\
\hline Song et al. (2015) & $\begin{array}{l}\text { A method for service modularization with modified service blueprint and fuzzy } \\
\text { graph. }\end{array}$ \\
\hline $\begin{array}{l}\text { Song and Chan } \\
(2015)\end{array}$ & idustria \\
\hline Kuo (2013)* & $\begin{array}{l}\text { A software design method utilizing Quality Function Deployment, module design, } \\
\text { and then cost evaluation (considering different business strategies). }\end{array}$ \\
\hline $\begin{array}{lll}\begin{array}{l}\text { Pezzotta } \\
(2013)\end{array} & \text { et al. } \\
\end{array}$ & $\begin{array}{l}\text { A service engineering framework that integrates a product-service design modeling } \\
\text { tool with a discrete event simulation test-bench. }\end{array}$ \\
\hline Song et al.(2013a) & $\begin{array}{l}\text { A systematic process to identify PSS requirements based on customer activity } \\
\text { cycle. }\end{array}$ \\
\hline Tu et al. (2013) * & Analysis of customization development procedures in PSS. \\
\hline $\begin{array}{lll}\begin{array}{l}\text { Akasaka } \\
(2012)\end{array} & \text { et al. } \\
\end{array}$ & $\begin{array}{l}\text { Design methodology of the integrated provision of products and services with } \\
\text { knowledge-based design support. }\end{array}$ \\
\hline Geum et al. (2011)* & $\begin{array}{l}\text { A framework for road mapping product-service integration according to the role of } \\
\text { involved technology. }\end{array}$ \\
\hline $\begin{array}{l}\text { Dong and } \mathrm{Su} \\
(2011)^{*}\end{array}$ & $\begin{array}{l}\text { A modeling approach adopting a meta-ontology of PSS configuration, fact base } \\
\text { and rule base. }\end{array}$ \\
\hline Wang et al. (2011) & $\begin{array}{l}\text { A framework for product-service lifecycle management and technologies of } \\
\text { development. }\end{array}$ \\
\hline Lee et al. (2010) & $\begin{array}{l}\text { Design framework composed of requirements identification and value targeting, } \\
\text { stakeholder activity design, function modeling, function-activity mapping and } \\
\text { concept generation, concept detailing and concept prototyping... }\end{array}$ \\
\hline Moon et al. (2009) & $\begin{array}{l}\text { An approach for developing service ontology to capture and reuse design } \\
\text { knowledge in a service family design using object-oriented concepts and an } \\
\text { ontology. }\end{array}$ \\
\hline $\begin{array}{l}\text { Kindström and } \\
\text { Kowalkowski } \\
\text { (2009) }\end{array}$ & $\begin{array}{l}\text { A generic four-stage framework of industrial service offerings based on market } \\
\text { sensing, development, sales, and delivery. }\end{array}$ \\
\hline $\begin{array}{l}\text { Waeyenbergh and } \\
\text { Pintelon (2009) }\end{array}$ & $\begin{array}{l}\text { A design framework which contains a decision support tool to choose the } \\
\text { appropriate maintenance policy and the right optimization model. }\end{array}$ \\
\hline Sundin et al. (2009) & $\begin{array}{l}\text { Elucidation on how mass customization could be enabled by adding more services } \\
\text { to customized products. }\end{array}$ \\
\hline $\begin{array}{l}\text { Sakao and } \\
\text { Shimomura (2007) }\end{array}$ & $\begin{array}{l}\text { Design framework consisting of flow model, scope model, view model and } \\
\text { scenario model. }\end{array}$ \\
\hline Sakao et al. (2007) & A method for customization in the level of RSP (receiver state parameter). \\
\hline Sakao (2007) & $\begin{array}{l}\text { A design methodology integrating life cycle assessment, quality function } \\
\text { deployment for environment, and TRIZ. }\end{array}$ \\
\hline Aurich et al. (2006) & $\begin{array}{l}\text { Design process for industrial services associated with products, and integrated with } \\
\text { the product design process. Modularization is used to integrate product and service } \\
\text { design processes by selecting, combining and adapting appropriate process } \\
\text { modules. }\end{array}$ \\
\hline
\end{tabular}


\begin{tabular}{|ll|}
\hline Morelli (2003) & $\begin{array}{l}\text { Design framework in which functions and requirements are connected with the } \\
\text { products elements and services elements. }\end{array}$ \\
\hline
\end{tabular}

\subsection{Knowledge gaps addressed by the paper}

As reviewed in Section 2.2, there is a lack of systematic methodical support covering the entire design process from requirements identification to concept configuration for PSS customization. This might be due to scientific lack of knowledge on which methods are available and/or difficulty in access to practice-oriented reports on customization.

Most of past researches have been dispersed in general description level without considering much about the framework implementation process or comprehensive design process. In particular, very few studies on design process for PSS customization have been conducted. For instance, PSS requirements generation from the analysis of customer activity cycles is often overlooked. Design conflict resolving is also often overlooked before modularization and PSS configuration in the past literature, which will lead to increase of conflicting goals during the decision-making of PSS configuration, and quality risks in later PSS delivery. Further, how sustainability could be addressed in PSS customization is still an open question as implied by (Sakao and Fargnoli 2010). Therefore, to fill in this gap, a comprehensive framework for PSS customization with supporting process needs to be developed.

\section{A design framework for sustainable PSS customization}

After identifying the knowledge gaps in Section 2.3, constructive research with experts was used to develop the customization-oriented framework of PSS. After developing the initial framework, the developers presented it to academic experts in research filed of PSS design. In addition, it had been discussed with industrial experts (including service engineers, designers, and service managers) who have substantial working experience (over 5 years) in the case company providing elevators. Each of the interviews was carried out by two researchers, lasting between 1h-1.5h. The feedbacks from both academic experts and practitioners were used to modify the framework.

\subsection{Definitions of the PSS design framework}

To provide a basis for design framework of PSS, the main terms are introduced and defined briefly in this section. These definitions provide a foundation for PSS design framework.

Definition 1: PSS design conflict-In PSS design process, improvement or enhancement of one PSS design attribute may lead to deterioration of another. Then, it can be considered that conflict exists between the two design attributes. For example, design attribute of service response time often conflicts with design attribute of service cost, because enhancement of response speed often needs to increase investment in service centers.

Definition 2: PSS component-PSS component is the basic element of Product/Service System. Generally, it is defined by a set of processes, operations, people or other objects. Different PSS components constitute service modules with different functions. For example, service engineer, service dispatching, and service tool library are PSS components in a module of service planning.

Definition 3: PSS module-PSS module integrates PSS components with strong interdependencies among each other. PSS components of different modules have little interdependencies, which gives service modules a high degree of independence among each other facilitating exchangeability. A PSS module is a set of components for performing a service function. 
There are two kinds of PSS module, i.e. mandatory service module and optional service module. Mandatory service module provides mainly basic service functions (e.g., a module of installation and commissioning), while optional service module is designed to be function carrier to meet personalized requirements (e.g., a module of energy saving). Each service module contains different module instance (e.g., remote installation guidance is an instance of a module of installation and commissioning) which is the concrete service content with different service performance.

Definition 4: PSS configuration-PSS configuration can be regarded as selecting proper PSS module instances to combine for a PSS alternative under certain constraints (e.g., response time, cost, and profits) to meet customer requirements. For example, selecting proper module instances to obtain a portfolio to achieve response time being not over one hour.

Definition 5: PSS concept-PSS concept is a general description of total solution that consists of a series of service processes, activities and service resources. It is expected to enhance the product function or overall performance during the product lifecycle. In this work, PSS concept refers to combination of a set of existing PSS module instances to support customer actions within the product lifecycle. For example, a set of Online knowledge support, Expert advisory, Remote installation guidance, Regular telephone follow up, Original spare parts supply, Emergency repair, Monthly maintenance, Monitoring, Outsourced dispatching, Energy performance contracting, and Component failure alert is a configured elevator PSS concept.

\subsection{The proposed PSS design framework for customization}

The proposed design framework is shown in Figure 1. The overall PSS customization framework consists of three levels: the top-level of PSS design process, the middle level of design methods and techniques and the bottom level of supporting data and knowledge. The top level of framework consists of four parts, namely, PSS requirements identification and analysis, technical attributes and conflict resolving, PSS modularization, and PSS configuration and concept selection. The design process domains are progressively connected with each other by design information mapping. PSS requirements identification and analysis aims to obtain critical inputs for the customization. Conflict solving of technical attributes aims to reduce possible defects in the customization process. The purpose of PSS modularization is to facilitate design reuse and make preparations for module-based configuration. PSS configuration aims to develop a PSS that satisfies the requirements with customized solutions based on existing modules from the phase of modularization.

The middle level of design methods includes specific design methods and techniques to support the PSS design process. The reasons for selecting these methods and techniques are explained in the Table 3. The bottom level of information and knowledge support is necessary as inputs. Product lifecycle information in the figure includes product health monitoring information and customer feedbacks. Table 4 summarizes key elements of the framework and how they were built. 


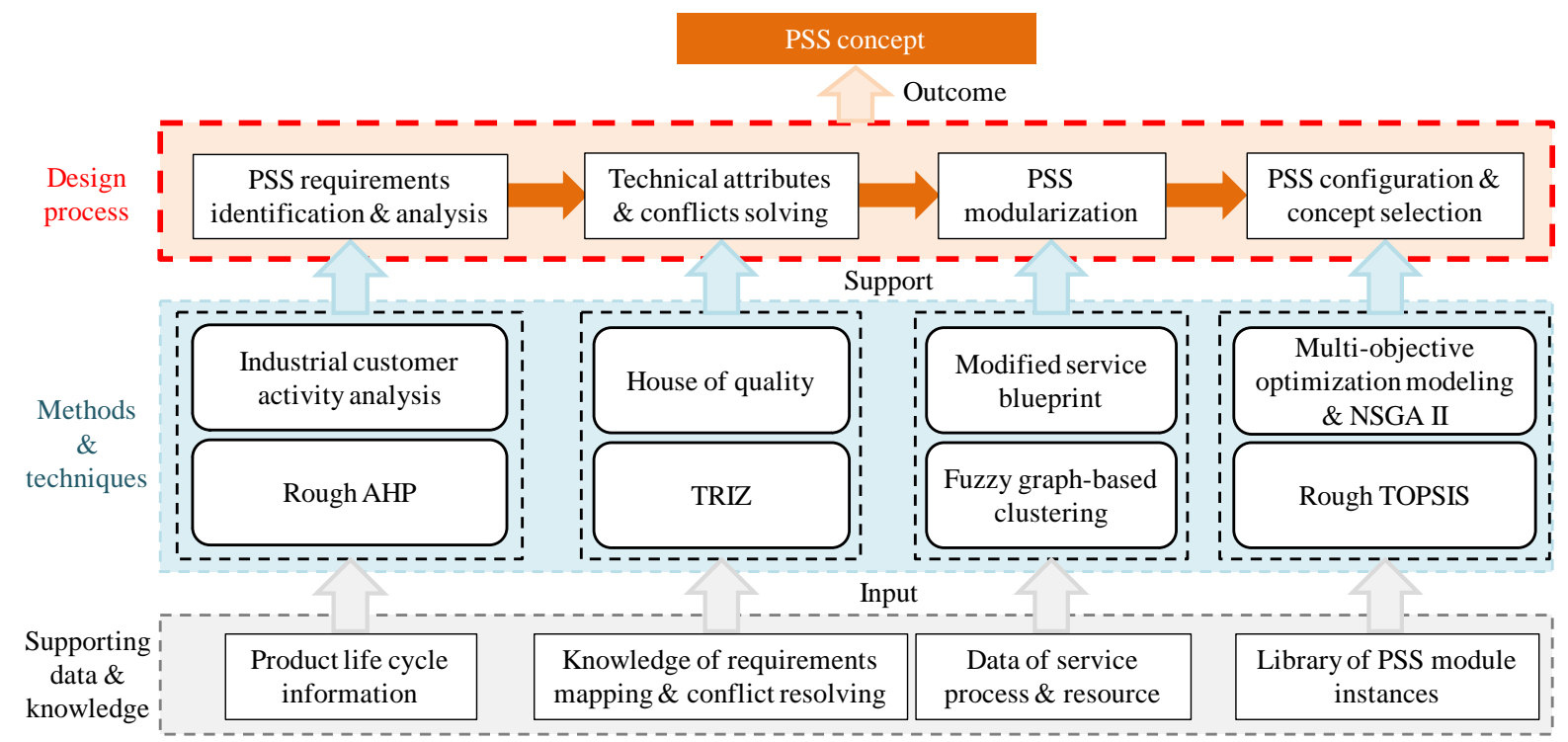

Figure 1. A design framework for sustainable Product/Service System.

Table 3.

Reason for selecting the methods and techniques in the proposed framework.

\section{Method and techniques Reason for use in the framework}

I-CAC (Industrial customer activity It systematically considers different stakeholders' involvement analysis) (Song et al., 2013a) and the full stages of customer using product.

Rough AHP (Analytic Hierarchy The Rough AHP has the strengths in prioritizing the fuzzy, Process) (Song et al., 2013a) subjective, and uncertain PSS requirements.

Rough HoQ (House of Quality) (Song et As a customer-oriented approach, it can effectively convert the al. 2014) based on HoQ (Hauser and PSS requirements into design attributes with vagueness, which Clausing, 1988) can be well understood and used by designers.

9-point rating scale assessment (Myint, It can indicate the degree of relationship between customer 2003) requirements and technical attributes.

TRIZ (Theory of inventive problem Contradiction Matrix and 40 inventive principles in TRIZ are solving) (Altshuller et al.,1999) effective tools to guide designers to solve design conflicts.

Modified service blueprint (Song et al., It can visually display the complex interactions between 2015) components in PSS for component identification.

Fuzzy graph-based clustering (Song et As a clustering method, it can cluster components with high al., 2015) interdependencies into PSS module.

Multi-objective optimization modeling It can be used to simultaneous optimization of multiple (Song and Chan, 2015) configuration objectives, e.g., PSS performance, cost, and response time.

NSGA II (Non-dominated sorting The NSGA-II avoids subjectivity in converting the multigenetic algorithm II) (Deb et al., 2002)

Rough TOPSIS (Technique for order of preference by similarity to ideal objective optimization model into the one with single objective. solution) (Song et al., 2013b) 
Table 4.

Key elements in the proposed framework and their sources.

\begin{tabular}{|c|c|}
\hline Key elements of the framework & Sources \\
\hline $\begin{array}{l}\text { PSS requirements identification and analysis, using product life cycle } \\
\text { information, and corresponding design process. }\end{array}$ & Song et al. (2013a) \\
\hline $\begin{array}{l}\text { Technical attributes and conflict resolving, support of requirements } \\
\text { mapping / conflict resolving, and corresponding design process. }\end{array}$ & $\begin{array}{l}\text { Sakao (2007), and Song and } \\
\text { Sakao (2016) }\end{array}$ \\
\hline $\begin{array}{l}\text { PSS modularization, using data of service process/resource, and } \\
\text { corresponding design process. }\end{array}$ & Song et al.(2015) \\
\hline $\begin{array}{l}\text { PSS configuration and concept selection, library of PSS modules, and } \\
\text { corresponding design process. }\end{array}$ & $\begin{array}{l}\text { Song and Chan (201 } \\
\text { Song et al. (2013b). }\end{array}$ \\
\hline
\end{tabular}

With the key elements in Table 4, the framework establishes throughput mechanism so that the output from one phase provides input to one or more of the following phases of PSS customization. As the framework shows, PSS customization starts from requirements identification and ends with customized concept selection to obtain the most suitable PSS solution. This process is shown with more details in Figure 2. Firstly, the PSS requirements are elicited and analyzed to get systematic and structured requirements. Then, the identified structured PSS requirements are converted into design attributes that designers can use. Meanwhile, potential design conflicts are also identified and resolved to facilitate later modularization and configuration. After that, the PSS provider scans the service solutions and capabilities to identify PSS components, and clusters them into modules. Finally, to effectively obtain reasonable customization concept, optimization model for module-based configuration is built and solved, respectively. 


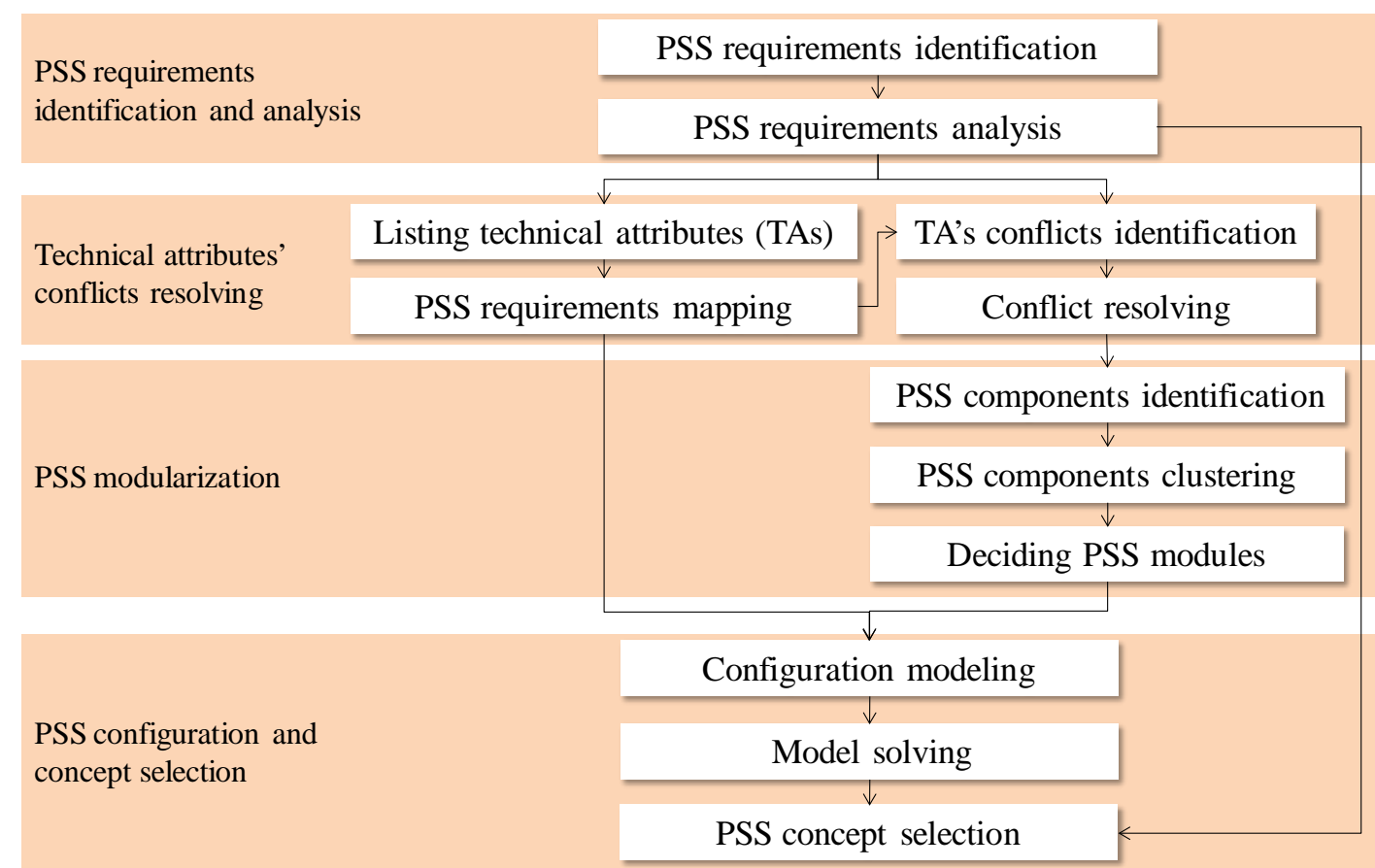

Figure 2. A design process of sustainable Product/Service System under the framework in Figure 1.

\subsubsection{PSS requirements identification and analysis}

Requirements are the starting point for conceptual design of PSS, and they are often considered to be the metrics of PSS customized concepts. It not only needs to identify requirements in product use phase, but also to identify requirements existing in other lifecycle phases, e.g., product acquisition, remanufacturing, recycling or disposal stage. Beside these common requirements, environmental requirements (such as energy saving) should also be identified and analyzed.

PSS requirements identification is closely related to different stakeholders, e.g., end users, product managers, and operators, etc. The method of I-CAC (Industrial customer activity analysis cycle) proposed in Song et al. (2013a) is used to obtain the PSS requirements around the customer activity cycle. Due to the diverse, imprecise and linguistic characteristic of PSS requirements, it is beneficial to group requirements into meaningful hierarchies to facilitate further analysis. Here, the identified requirements can be structured into groups. After that, Rough AHP (Rough Analytic Hierarchy Process) (Song et al., 2013a) based on the traditional AHP (Saaty, 1988) can be used to prioritize PSS requirements. Requirement priority analysis can help designers to allocate resources for the follow-up design activities. It will also serve as critical inputs for PSS concept evaluation in the configuration phase. The specific methods are not discussed here due to the space limit and the focus of this research.

\subsubsection{Technical attributes' conflicts resolving}

Based on the analysis of PSS requirements and designers' experience, the PSS technical attributes (TAs) can be derived. Then, in order to achieve PSS requirements conversion, the basic structure of House of Quality (HoQ) (Hauser and Clausing, 1988) is used in this phase to convert the PSS requirements from different stakeholders into TAs, which can be well 
understood and used by designers. These technical attributes include both basic PSS functions and environmental measures. The degree of relationships between PSS requirements and the service technical attributes are judged by designers with the 9-point rating scale assessment (Myint, 2003). Meanwhile, the priorities of TAs are calculated with the method proposed in Song et al. (2014), which provides critical inputs for the subsequent PSS configuration.

After completing the PSS requirements mapping, correlation matrix in the roof of HoQ is utilized to identify possible conflicts between TAs. Negative correlations in roof of HoQ indicate potential conflicts between technical attributes. Then, these negative correlations can be linked to conflict matrix of TRIZ and 40 inventive principles (Sakao, 2007; Song and Sakao, 2016). The TAs with conflict are standardized into the parameters in contradiction matrix of TRIZ. The preliminary conflict resolving principles can be available by searching contradiction matrix of TRIZ. Designers can then obtain the final specific conflict resolution under the guidance of preliminary conflict resolving principles. In this way, potential conflict between TAs can be solved. Conflict identification and resolving in the early design phase is expected to address PSS potential failure, reduce conflicting goals, and improve customer satisfaction.

\subsubsection{PSS modularization}

In order to quickly respond to personalized requirements, some common components can be used in the process of PSS design. In this way, service process simplification, service resource sharing, and service cost reduction are expected to be achieved. PSS module contains components with strong interdependencies. While PSS components in different modules have little interdependencies, which ensures modules to have high exchangeability. Heterogeneous elements (such as service personnel, service object and service process) make the structure of PSS more complicated. Specific steps of PSS modularization are described as follows.

Firstly, all the related PSS components are identified. Modified service blueprint (Song et al., 2015) is used to identify all the related PSS components including service processes, service objects and service resources. Modified service blueprint contains five different functional areas, namely product using domain, product management domain, visualized service domain (foreground), invisible service domain (background) and resources domain.

Secondly, interdependencies between different components are analyzed with pair-wise comparison method from the perspective of process, function and resource.

Finally, components are clustered into PSS modules with clustering methods, such as fuzzy tree graph-based approach (Song et al., 2015) which can visually show interdependency strengths between various PSS components. Some environmental components are also clustered together to be an environmental module of PSS, e.g. energy-saving module, waste management module, and module of residual heat and pressure reusing. These PSS modules can be reused in future design. Due to the limited space, the specific methods are not repeated here. Interested readers are encouraged to read Song et al. (2015).

\subsubsection{PSS configuration and concept selection}

Configuration is an efficient method for rapid PSS customization to enhance customer satisfaction. Modular PSS configuration refers to the selection of right service module instances to combine into integral PSS solutions to meet customer requirements with certain constraints.

The steps of PSS configuration are described as follows: Firstly, relationships between technical attributes and module instances are identified. In this way, technical attributes derived from customer requirements can be converted into configuration requirements of the module instances. Secondly, appropriate module instances are retrieved in accordance with the 
configuration requirements and constraints to obtain an optimized service portfolio. Specifically, a module instance is selected for each module in the mandatory modules. After that, optional modules are selected from the optional module set, and then an module instance is selected for each of these optional modules. Thirdly, PSS concept composed by the module instances (mandatory and optional) can be obtained.

In fact, PSS configuration can be regarded as the combinatorial optimization of service modules to maximize fulfillment of customer requirements. Proper service module instances are selected from the existing set of module instances according to correlations between technical attributes and module instances. This is a typical problem of multi-objective combinatorial optimization with constraints, because PSS configuration optimization model often simultaneously takes service performance, cost, and response time as the optimization objectives. After that, the multi-objective optimization model can be solved with methods such as NSGA II (Non-dominated sorting genetic algorithm II) (Deb et al., 2002), to obtain the optimized configuration set (the specific implementation steps are not repeated due to the limited space here). Interested readers are encouraged to read Song and Chan (2015) that describes the specific process of configuration optimization. The optimized configuration set contains all the feasible solutions of the customized PSS concepts, which can meet the constraints and pre-set goals. Then, most suitable concept can be selected with a method of rough TOPSIS (Song et al., 2013b) in subjective environments (the specific implementation steps are not repeated due to the limited space here). Interested readers are encouraged to read Song et al. (2013b) which describes the method of design concept selection under subjective environments.

In the proposed framework, the relationships between technical attributes (converted from PSS requirements) and module instances are identified to link them with the specific configuration requirements. Meanwhile, the configuration set of feasible PSS solutions is assessed with customer preference and requirements. All of these ensure that the PSS customization framework can achieve closed-loop process, i.e., from the beginning of requirements identification to the end of requirements fulfillment by flexible configuration. Moreover, conflict resolving before PSS configuration can reduce conflicting goals of the configuration decision-making, which will largely alleviate burden of solving multi-objective optimization model for PSS configuration.

\section{Case study}

To illustrate the proposed PSS design framework, it was applied to an elevator manufacturing Company $\mathrm{M}$ in China. A single case was chosen for this study in order to get an in-depth view of the framework implementation. The case Company $\mathrm{M}$ was selected, as it decided to transform from an elevator manufacturer to an elevator solution provider. In this section, implementation of the proposed design framework of PSS in Company $M$ is first briefly presented. Further, effects of PSS design framework are analyzed and discussed. Comparisons between past elevator service design and design after implementing the framework in Company $\mathrm{M}$ are also conducted to show the feasibility and effectiveness of the framework.

Elevator Company $\mathrm{M}$ is a leading manufacturer who provides different types of elevators including passenger/freight elevator, hospital elevator, escalator, and elevator monitoring system, etc. Some standard after-sales services were offered without considering meeting the personalized requirements. Moreover, customers complained much about the failure in later 
service delivery, and some critical service requirements in elevator lifecycle were often overlooked, because they had not been expressed by customers. In this respect, Company $\mathrm{M}$ decided to provide customized PSS to ensure efficiency and effectiveness of elevator operation. The PSS customization project team in Company M included company director, marketing engineers, designers, service engineers, and customer service managers, and they used the framework in the project. The first author and some other researchers (postgraduates) took the role of participatory consultants (or even part-time project engineers) to help Company $\mathrm{M}$ to discuss its issues as well as to create and implement solutions.

The data was collected through several visits and two graduate student internships at Company M. Interview can offer a basis for discussion of particular aspects of a framework implementation and it is also a flexible and suitable way to find strategic information. Therefore, semi-structured interviews with (sixteen) practitioners were mainly conducted to adapt the initial framework to the evaluator PSS customization project, as well as to validate the effectiveness of the framework. The involved 16 practitioners included one company director, two operations managers, seven designers, three service managers, and three service engineers at Company M. The duration of interviews was 1-1.5 hours. Beside the interviews, analysis of available reports (e.g., operations analysis report of customer service center) and observations (e.g., maintenance and repair process) were used to collect objective data (e.g., about elevator service process, service cost), because these methods require a minimal level of interaction between the researchers and practitioners and, thus, is bound to a minimal level of bias in the results.

\subsection{Application of the PSS design framework}

\subsubsection{PSS requirements identification and analysis}

Figure 3 shows the customer activity cycle for elevator. The central portion of the circle depicts an elevator. The intermediate ring of the Figure 3 includes different customer activities in elevator using phase, e.g., elevator configuration, purchase analysis, installation and commissioning, and elevator operation, etc. The outer ring in Figure 3 contains stakeholders (e.g., real estate developer, real estate owners, and elevator manufacturer) playing different roles in different phase of customer activity cycle. Interviews were conducted to elicit stakeholders' requirements in different phase of customer activity cycle. The original requirements from interviews were decomposed, merged and simplified into a requirement hierarchical structure (see Table 5). 


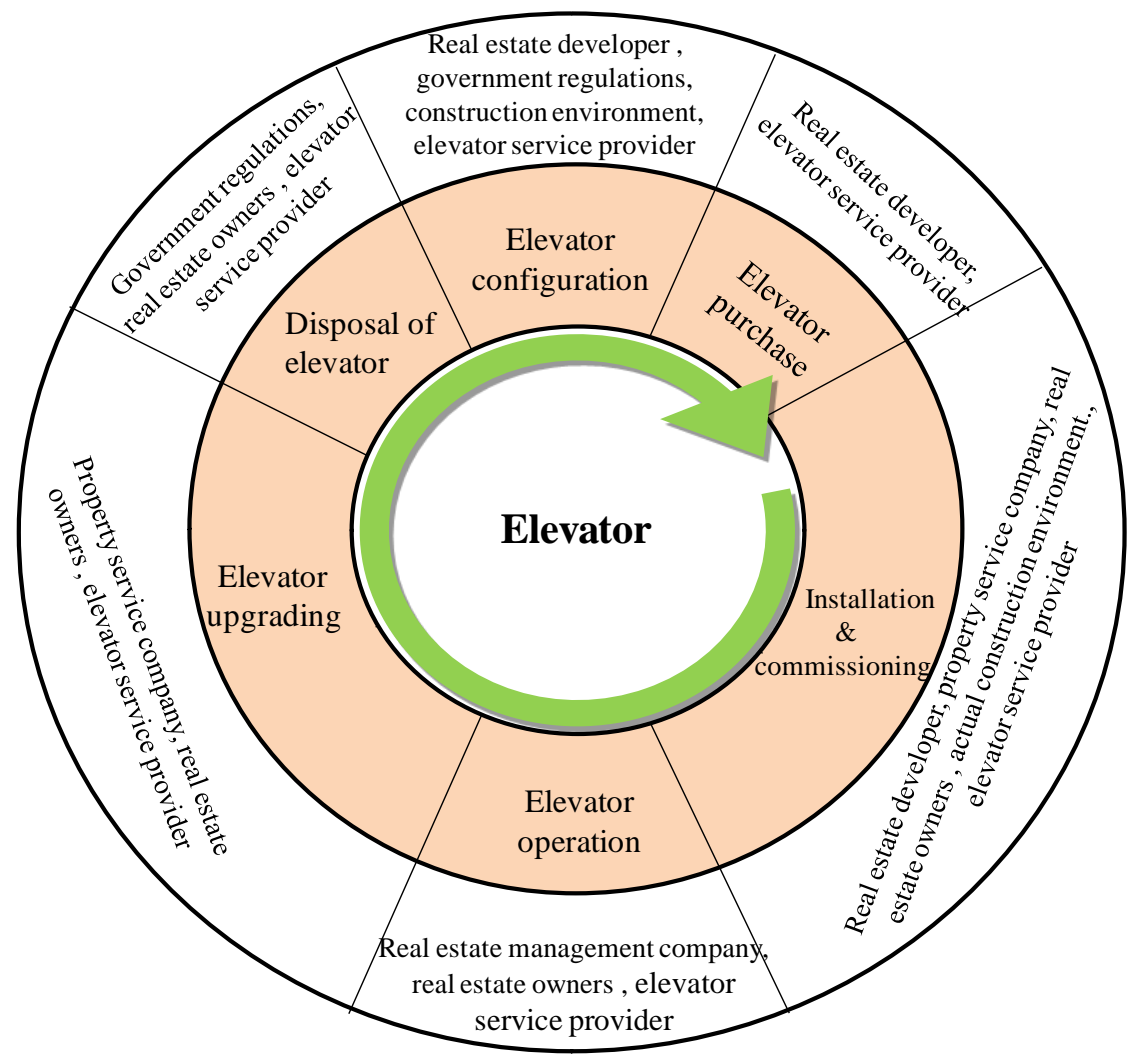

Figure 3. Customer activity cycle of elevator in Company M.

Table 5.

Customer requirements of passenger elevator service.

\begin{tabular}{|c|c|c|c|}
\hline Customer activity cycle & $\begin{array}{c}\text { Customer } \\
\text { requirement }\end{array}$ & Sub-requirement & $\begin{array}{l}\text { Requirement } \\
\text { importance }\end{array}$ \\
\hline $\begin{array}{l}\text { Elevator configuration } \\
\text { \& purchase, }\end{array}$ & \multirow{2}{*}{$\begin{array}{l}\text { Quickly acceptance } \\
\text { test and being in use } \\
\text { of elevator }\left(\mathrm{R}_{1}\right)\end{array}$} & $\begin{array}{l}\text { Professional and customized advisory } \\
\text { on purchasing and using elevator } \\
\left(\mathrm{R}_{11}\right)\end{array}$ & 0.018 \\
\hline $\begin{array}{l}\text { Installation \& } \\
\text { commissioning }\end{array}$ & & $\begin{array}{l}\text { Timely and professional installation } \\
\text { including construction and } \\
\text { commissioning }\left(\mathrm{R}_{12}\right)\end{array}$ & 0.052 \\
\hline \multirow{4}{*}{ Elevator operation } & \multirow{3}{*}{$\begin{array}{l}\text { Safe and reliable } \\
\text { operation of elevator } \\
\left(\mathrm{R}_{2}\right)\end{array}$} & $\begin{array}{l}\text { Fewer accidents (e.g. elevator } \\
\text { dropping ) resulting in casualties } \\
\left(\mathrm{R}_{21}\right)\end{array}$ & 0.797 \\
\hline & & $\begin{array}{l}\text { Fewer failures (e.g. circuit } \\
\text { breakdown ) resulting in shutdown of } \\
\text { elevator }\left(\mathrm{R}_{22}\right)\end{array}$ & 0.217 \\
\hline & & Long service life of elevator $\left(\mathrm{R}_{23}\right)$ & 0.132 \\
\hline & $\begin{array}{l}\text { Low operating costs of } \\
\text { elevator }\left(R_{3}\right)\end{array}$ & $\begin{array}{l}\text { Lower maintenance costs (e.g., labor } \\
\text { cost, consumable cost and spare part } \\
\text { cost) }\left(\mathrm{R}_{31}\right)\end{array}$ & 0.162 \\
\hline \multirow{3}{*}{ Elevator upgrading } & \multirow{2}{*}{$\begin{array}{l}\text { Flexible service with } \\
\text { quick response }\left(\mathrm{R}_{4}\right)\end{array}$} & $\begin{array}{l}\text { Quick response to service request of } \\
\text { customer }\left(\mathrm{R}_{41}\right)\end{array}$ & 0.361 \\
\hline & & $\begin{array}{l}\text { Various types of service contracts to } \\
\text { satisfy personalized needs }\left(\mathrm{R}_{42}\right)\end{array}$ & 0.098 \\
\hline & Lifecycle energy & Low power consumption and efficient & 0.099 \\
\hline
\end{tabular}


saving of elevator $\left(\mathrm{R}_{5}\right)$ energy use in elevator lifecycle $\left(\mathrm{R}_{51}\right)$

After identifying elevator PSS requirements, five experts from various fields were invited to judge the importance of each requirement. The five experts were representative of the real estate owners, building developer representative, elevator service manager, property service manager and representative of elevator service engineers. The final importance of PSS requirements (also see Table 5) was calculated with the method of rough group AHP proposed in Song et al. ( 2013a). As can be seen from the Table 5, requirement $\mathrm{R}_{21}$ (fewer accidents) was ranked the first in requirement list. $\mathrm{R}_{41}$ (quick service response) came in the second place, because the service response time would affects customer satisfaction and experience. For the high-rise building, especially commercial high-rise building, the shut-down of elevator not only brings inconvenience of daily travel, but also may lead to security incidents. Therefore, $\mathrm{R}_{22}$ (fewer failures of shut-down) was also given a high priority.

\subsubsection{Technical attributes' conflicts resolving}

After obtaining the PSS requirements and their requirements, service technical attributes were derived from the current service resources and functions in the company. Those elevator service technical attributes are provided in Table 6. $\mathrm{TA}_{12}$ was considered as an environmental attribute, because it could help to save power by upgrading the elevator with an energy feedback system. Table 6.

The technical attributes of elevator service.

\begin{tabular}{|c|c|c|}
\hline $\begin{array}{l}\text { Technical } \\
\text { attribute }\end{array}$ & Name & Description \\
\hline $\mathbf{T A}_{1}$ & $\begin{array}{l}\text { Professional level of } \\
\text { elevator purchase guidance }\end{array}$ & $\begin{array}{l}\text { Capability to provide guidance for customer to select the } \\
\text { most suitable elevator in terms of the building } \\
\text { environment. }\end{array}$ \\
\hline $\mathbf{T A}_{2}$ & $\begin{array}{l}\text { Efficiency of installation } \\
\text { and commissioning }\end{array}$ & $\begin{array}{l}\text { Efficiency of installation and commissioning services } \\
\text { for quick start and safe use of elevator. }\end{array}$ \\
\hline $\mathbf{T A}_{3}$ & $\begin{array}{l}\text { Coverage of condition } \\
\text { monitoring }\end{array}$ & $\begin{array}{l}\text { Scope of condition monitoring to guarantee grasping } \\
\text { real-time running state of the elevator. }\end{array}$ \\
\hline $\mathbf{T A}_{4}$ & $\begin{array}{l}\text { Accuracy of failure } \\
\text { diagnosis }\end{array}$ & $\begin{array}{l}\text { Failure diagnosis accuracy based on expert knowledge } \\
\text { and elevator condition information. }\end{array}$ \\
\hline $\mathbf{T A}_{5}$ & Level of maintenance & $\begin{array}{l}\text { Maintenance service level to keep the elevator in good } \\
\text { condition. }\end{array}$ \\
\hline $\mathbf{T A}_{6}$ & $\begin{array}{l}\text { Effectiveness of elevator } \\
\text { operation training }\end{array}$ & $\begin{array}{l}\text { Customer' s knowledge/skill of safe use and basic } \\
\text { maintenance acquired from training. }\end{array}$ \\
\hline $\mathbf{T A}_{7}$ & Level of repair service & $\begin{array}{l}\text { Repair service capability to quickly restore elevator's } \\
\text { functionality. }\end{array}$ \\
\hline $\mathbf{T A}_{8}$ & Cost of spare parts supply & $\begin{array}{l}\text { Cost of interchangeable part kept in an inventory and } \\
\text { supplied for the repair or replacement of failed units. }\end{array}$ \\
\hline $\mathbf{T A}_{9}$ & $\begin{array}{l}\text { Coverage of service } \\
\text { network }\end{array}$ & $\begin{array}{l}\text { Scope of service network that ensures the availability of } \\
\text { the elevator service for customers. }\end{array}$ \\
\hline $\mathbf{T A}_{10}$ & Time of service dispatching & $\begin{array}{l}\text { Time of dispatching service technicians to meet certain } \\
\text { service response requirement. }\end{array}$ \\
\hline $\mathbf{T A}_{11}$ & $\begin{array}{l}\text { Availability of emergency } \\
\text { repair }\end{array}$ & $\begin{array}{l}\text { Repair service availability in emergency circumstances, } \\
\text { e.g., rescuing people trapped in the elevator. }\end{array}$ \\
\hline $\mathbf{T A}_{12}$ & $\begin{array}{l}\text { Technical level of elevator } \\
\text { retrofit \& upgrading }\end{array}$ & $\begin{array}{l}\text { Retrofits and upgrading technology level for safe and } \\
\text { efficient operation in the later stage of elevator lifecycle. }\end{array}$ \\
\hline
\end{tabular}


Table 7.

Correlations between PSS requirements and technical attributes.

\begin{tabular}{|c|c|c|c|c|c|c|c|c|}
\hline & $\mathbf{T A}_{1}$ & $\mathbf{T A}_{2}$ & ... & TA9 & $\mathbf{T A}_{10}$ & TA $_{11}$ & $\mathbf{T A}_{12}$ & $\begin{array}{c}\text { Weights of } \\
\text { elevator } \\
\text { service } \\
\text { requirements }\end{array}$ \\
\hline $\mathbf{R}_{11}$ & $9,9,7,7,9$ & & $\ldots$ & $1,1,3,1,3$ & & & & 0.018 \\
\hline $\mathbf{R}_{12}$ & $3,3,1,3,3$ & 9,7,9,9,9 & $\ldots$ & $5,3,3,3,5$ & $5,5,5,3,5$ & $3,5,3,3,5$ & & 0.052 \\
\hline $\mathbf{R}_{21}$ & $1,1,3,1,3$ & $5,5,5,3,5$ & $\ldots$ & & & $7,5,5,5,5$ & $5,5,7,7,5$ & 0.797 \\
\hline $\mathbf{R}_{22}$ & $3,1,3,3,3$ & $5,5,3,5,3$ & $\ldots$ & & & & $5,3,3,3,3$ & 0.217 \\
\hline$\ldots$ & & & & & & & & $\ldots$ \\
\hline $\mathbf{R}_{\mathbf{4 2}}$ & & & $\ldots$ & $9,7,7,7,7$ & $7,5,5,7,7$ & $7,9,7,9,9$ & & 0.098 \\
\hline $\mathbf{R}_{51}$ & $5,7,7,5,7$ & $3,3,3,3,3$ & $\ldots$ & & & & $7,9,7,7,9$ & 0.099 \\
\hline $\begin{array}{l}\text { Weights of elevator } \\
\text { service technical } \\
\text { attributes }\end{array}$ & 0.0815 & 0.0834 & & 0.0826 & 0.0829 & 0.0834 & 0.0839 & - \\
\hline
\end{tabular}

Then, the elevator service design engineers analyzed relationships between PSS requirements and the service technical attributes under the structure of HoQ. The weights of the elevator service technical attributes are listed in the Table 7. TAs' Weights were calculated with rough HoQ in Song et al. (2014). Part of the technical attributes is not listed in Table 7 due to limited space. Table 7 also shows correlations between PSS requirements and technical attributes. The relationships between technical attributes and requirements were judged by the service design team consisting of five designers. The five designers judged the degree of relationship with the method of 9-point rating scale assessment (Myint, 2003). The design group then analyzed the correlations between different service technical attributes to obtain those attributes with negative correlations in the HoQ. The five designers were involved in conflict identification process. Improvement or enhancement of one elevator service technical attribute may cause the deterioration of another. In this case, it is considered that conflict exists between the two elevator service technical attributes. Here, an identified conflict between $\mathrm{TA}_{9}$ (Wide coverage of service network) and $\mathrm{TA}_{10}$ (Short time of service dispatching), is used to illustrate the conflict resolving process.

Firstly, the design team analyzed the correlations between different elevator service technical attributes to identify attributes with negative correlations, and they found $\mathrm{TA}_{9}$ (Coverage of service network) and $\mathrm{TA}_{10}$ (Time of service dispatching) were negatively correlated. Thus, the design team considered that potential conflicts may exist between $\mathrm{TA}_{9}$ and $\mathrm{TA}_{10}$. In fact, under conditions of limited service resources, wide coverage of service network would make dispatching time increase, and eventually lead to the increase of customer waiting time.

Secondly, two TRIZ experts were invited to help to represent the $\mathrm{TA}_{9}$ and $\mathrm{TA}_{10}$ with the standardized parameters in TRIZ. TA 9 was represented with the $33^{\text {rd }}$ TRIZ parameter "Ease of operation" (Simplicity: The process is NOT easy if it requires a large number of people, large number of steps in the operation, needs special tools, etc. "Hard" processes have low yield and "easy" process have high yield; they are easy to do right) (Altshuller et al.,1999). While TA 10 was represented with the $25^{\text {th }}$ TRIZ parameter "Loss of time" (Time is the duration of an activity. Improving the loss of time means reducing the time taken for the activity) (Altshuller et al.,1999). 
Thirdly, the contradiction matrix in TRIZ was examined to find out the favorable inventive principles. The TRIZ parameter "33. Ease of operation" was detected by the design team as "improving parameter" in the columns, while "25. Loss of time" was detected as "worsening parameter" in the rows. Then, to find the recommend inventive principles, designers searched through the intersection of the improving and worsening TRIZ parameters in contradiction matrix. Four inventive principles were recommended to resolve conflict between $\mathrm{TA}_{9}$ and $\mathrm{TA}_{10}$. They were principle 4 (Asymmetry), 28 (Mechanics substitution), 10 (Preliminary action) and 34 (Discarding and recovering) respectively.

After discussion with TRIZ experts, the design team decided to select inventive principle10 (Preliminary action) to resolve the conflict. According to the sub-principle of the inventive principle 10 ("Pre-arrange objects such that they can come into action from the most convenient place and without losing time for their delivery” (Altshuller et al.,1999)), it was necessary to provide service skill training for works in advance, and keep the service facilities in good condition. Specifically, to reduce customer waiting time, a precise dispatching method based on GIS (Geographic Information System ) was proposed to optimize service route and resources in advance.

\subsubsection{PSS modularization}

Firstly, the modified service blueprint in our previous research (Song et al., 2015) was used to represent the whole scenario of elevator PSS in Figure 4. In Figure 4, there are different customers-involved activities in the visualized service domain, e.g., elevator operation training, installation, and maintenance which relies on supports of components in the resources domain (e.g., service engineer and service tool library). The non-visualized service domain (due to the limited space) includes installation tasks assignment, maintenance planning, and upgrading analysis, etc. The activity of "safe operation of elevator" in product using domain is mainly to achieve reliable and efficient use of elevator. Product management domain includes three activities, i.e., real-time data acquisition, remote inspection and malfunction alarm. All the activities in both product domain and service domain require supports from resource domain. Therefore, the service components of the elevator PSS in each domain can be identified with the modified service blueprint (represented by the boxes in Figure 4). A total of 50 elevator service components were identified in the modified service blueprint.

Secondly, interdependencies between the 50 identified components (see Table 8) were analyzed with pair-wise comparison method to obtain the interdependencies between elevator service components.

Finally, the fuzzy graph-based modularizing method proposed in Song et al. (2015) was used to cluster the service components into 13 PSS modules. All the elevators PSS modules are listed in Table 8. The PSS components in Table 8 were identified from the Figure 4, and the elevator PSS modules were obtained with the method in Song et al. (2015). Only part of the elevator PSS modules is provided in Table 8 due to the limited space. 


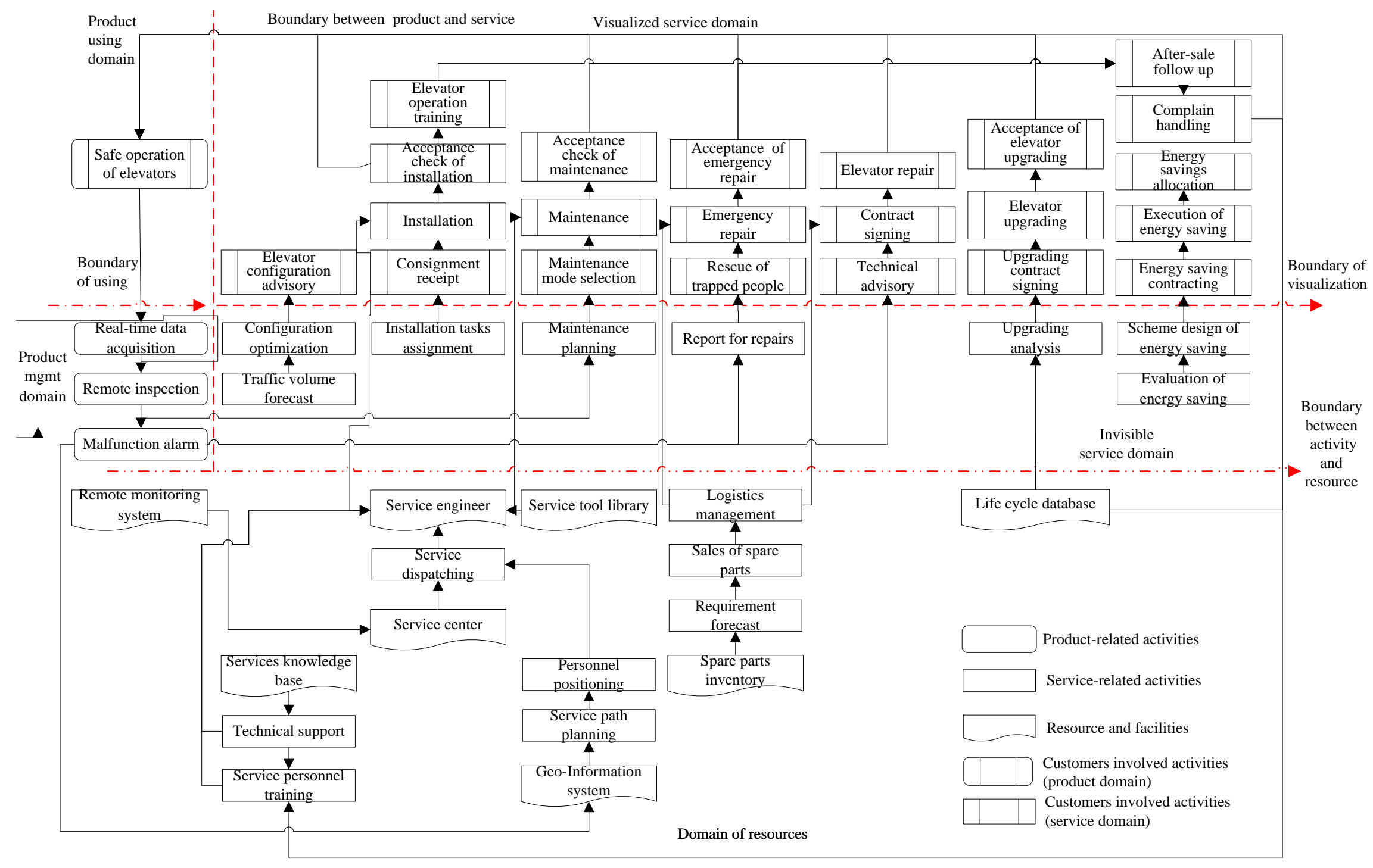

Figure 4. The modified service blueprint for elevator PSS. 
Table 8.

Elevator PSS module and components.

\begin{tabular}{|c|c|c|}
\hline NO. & $\begin{array}{l}\text { Elevator PSS } \\
\text { module }\end{array}$ & Elevator PSS components \\
\hline 1 & $\begin{array}{l}\text { Service knowledge } \\
\text { support }\end{array}$ & $\begin{array}{l}\text { Services knowledge base, Technical support, Service personnel } \\
\text { training }\end{array}$ \\
\hline 2 & Purchase consulting & $\begin{array}{l}\text { Elevator configuration advisory, Elevator configuration } \\
\text { optimization, Traffic volume forecast }\end{array}$ \\
\hline 3 & $\begin{array}{l}\text { Installation and } \\
\text { commissioning }\end{array}$ & $\begin{array}{l}\text { Elevator operation training, Acceptance check of installation, } \\
\text { Installation, Consignment receipt, Installation tasks assignment }\end{array}$ \\
\hline 4 & Customer care & After-sale follow up, Complaints handling \\
\hline 5 & $\begin{array}{l}\text { Elevator service } \\
\text { planning }\end{array}$ & $\begin{array}{l}\text { Service engineer, Service dispatching, Service center, Service } \\
\text { tool library }\end{array}$ \\
\hline 6 & Repair & Elevator repair, Repair contract signing, Technical advisory \\
\hline$\ldots$ & .. & $\ldots$ \\
\hline 12 & $\begin{array}{l}\text { Life-cycle data } \\
\text { analysis }\end{array}$ & Lifecycle database \\
\hline 13 & $\begin{array}{l}\text { Energy-saving of } \\
\text { elevator }\end{array}$ & $\begin{array}{l}\text { Evaluation of energy saving, Scheme design of energy saving, } \\
\text { Energy saving contracting, Execution of energy saving, Energy } \\
\text { savings allocation }\end{array}$ \\
\hline
\end{tabular}

\subsubsection{PSS configuration and concept selection}

The elevator service modules and module instances are shown in Table 9. The service module instances ( $\boldsymbol{\Delta}$ : mandatory module, $\boldsymbol{\Delta}$ : optional module) and their cost and response time in Table 9 were provided by the designers and managers in Company M. Only part of data is listed here due to privacy restrictions. The module instances in Table 9 can be used in the first step of configuration to establish configuration requirements. Besides, the modules and module instances in Table 9 are the critical input of the multi-objective configuration optimization modeling of elevator PSS in the second step of configuration. The different specifications of module instances (i.e., cost , response time, and module property) in Table 9 constitute constraints of the configuration optimization model. Moreover, these module instances with different specifications can be combined into the final solutions for the third step of configuration. 
Table 9.

Elevator service modules and module instances

\begin{tabular}{|c|c|c|c|c|}
\hline $\begin{array}{c}\text { Service module } \\
\text { name }\end{array}$ & Module instance & $\begin{array}{l}\text { Cost (ten } \\
\text { thousand } \\
\text { yuan) }\end{array}$ & $\begin{array}{c}\text { Response } \\
\text { time (hour) }\end{array}$ & $\begin{array}{l}\text { Module } \\
\text { property }\end{array}$ \\
\hline \multirow{3}{*}{$\begin{array}{l}\text { Service knowledge } \\
\text { support }\end{array}$} & $\begin{array}{l}\text { Online knowledge support } \\
\text { with internet }\end{array}$ & 1.25 & 0.3 & $\Delta$ \\
\hline & $\begin{array}{l}\text { Remote knowledge support } \\
\text { with telephone }\end{array}$ & 1.54 & 0.3 & $\Delta$ \\
\hline & $\begin{array}{l}\text { On-site technology training } \\
\text { by experts }\end{array}$ & 2.55 & 1.5 & $\Delta$ \\
\hline \multirow{2}{*}{$\begin{array}{l}\text { Purchase } \\
\text { consulting }\end{array}$} & $\begin{array}{l}\text { Personalized expert } \\
\text { advisory for elevator } \\
\text { purchase }\end{array}$ & 0.50 & 3.5 & $\Delta$ \\
\hline & $\begin{array}{l}\text { Standardized online self- } \\
\text { advisory for elevator } \\
\text { purchase }\end{array}$ & 0.30 & 0.2 & $\Delta$ \\
\hline \multirow{3}{*}{$\begin{array}{l}\text { Installation and } \\
\text { commissioning }\end{array}$} & $\begin{array}{l}\text { Remote installation } \\
\text { guidance with internet }\end{array}$ & 1.25 & 8 & $\Delta$ \\
\hline & $\begin{array}{l}\text { On-site installation } \\
\text { guidance from experts }\end{array}$ & 0.62 & 16 & $\Delta$ \\
\hline & $\begin{array}{l}\text { Turnkey service for } \\
\text { installation \& } \\
\text { commissioning }\end{array}$ & 2.50 & 8 & $\Delta$ \\
\hline \multirow{3}{*}{ Customer care } & $\begin{array}{l}\text { Regular telephone follow- } \\
\text { up }\end{array}$ & 1.55 & 0.5 & $\Delta$ \\
\hline & $\begin{array}{l}\text { Random telephone follow- } \\
\text { up }\end{array}$ & 0.96 & 6.2 & $\Delta$ \\
\hline & $\begin{array}{l}\text { Follow-up based on } \\
\text { customer complaints }\end{array}$ & 1.24 & 5.5 & $\Delta$ \\
\hline$\ldots$ & $\ldots$ & $\ldots$ & $\ldots$ & $\ldots$ \\
\hline \multirow{2}{*}{$\begin{array}{c}\text { Lifecycle data } \\
\text { analysis (optional) }\end{array}$} & $\begin{array}{l}\text { Proactive lifecycle alert of } \\
\text { component failure based on } \\
\text { real-time monitoring }\end{array}$ & 0.64 & 0.5 & $\Delta$ \\
\hline & $\begin{array}{l}\text { Maintenance information } \\
\text { inquiry and reporting after } \\
\text { failure occurs }\end{array}$ & 0.88 & 0.5 & $\Delta$ \\
\hline \multirow[t]{2}{*}{$\begin{array}{l}\text { Energy-saving of } \\
\text { elevator (optional) }\end{array}$} & $\begin{array}{l}\text { Energy management } \\
\text { contracting (EMC) based on } \\
\text { the energy-saving } \\
\text { performance }\end{array}$ & 3.58 & 8 & $\Delta$ \\
\hline & $\begin{array}{l}\text { Disposable payment for } \\
\text { energy-saving retrofit based }\end{array}$ & 5.16 & 8 & $\Delta$ \\
\hline
\end{tabular}


Firstly, the relationship between each technical attribute obtained in section 4.1.2 and module instance in Table 9 was identified. Scores of $9,3,1$, and 0 were used to indicate very strong, strong, weak, and no relationship between technical attributes and PSS module instances, respectively (Song and Chan, 2015). Thus, correlations between technical attributes and module instances were determined.

Secondly, the multi-objective configuration optimization model was built based on correlations and constraints. The goal of elevator PSS configuration optimization model was built to search for a proper module instance portfolio to achieve relative optimum of overall PSS performance, i.e., the optimized service solution should have the best service performance, shortest response time and lowest service cost. The elevator PSS configuration was required to meet constraints including: Company $\mathrm{M}$ 's expected profit margin is 25\%; The highest price of elevator service that customer can afford is RMB $¥ 300,000$; And the tolerable total response time of customer is 50 hours.

Thirdly, the model was solved with the NSGA II to obtain the optimized PSS configuration set. The selected optimized elevator PSS concept with rough TOPSIS (Song et al., 2013b) from the solution set is A1. Elevator PSS concept A1 is a set of Online knowledge support with internet, Personalized expert advisory for elevator purchase, Remote installation guidance with internet, Regular telephone follow-up, Maintenance with non-original spare parts, Collaborative emergency repair with partners, Traditional spare parts supply, Maintenance/semimonthly, Operation monitoring, Outsourced dispatching, Energy management contracting (EMC) based on the energy-saving performance, and Proactive lifecycle alert of component failure based on real-time monitoring. Concept A1 includes 12 modules, its total service cost is RMB $¥ 173,200$, and total response time is 31.1 hours.

\subsection{Effects and implications of framework}

In order to assess the effects of the PSS design framework in Company M, 15 semistructured interviews (each lasts 1-1.5 hours) with 4 academic researchers and 16 industrial experts in Company $\mathrm{M}$ were conducted. The 4 academic researchers were familiar with product engineering, service engineering, PSS, and sustainability; while other industrial experts included one company director, five senior managers (three service managers and two operation managers), seven designers and three service engineers. Their names were not shown in the paper due to confidentiality. The interviews focused on the difference between the previous elevator PSS design and PSS design with support of the framework. Thus the questions used in the interviews were related to requirement identification, potential conflicts resolving of design attributes, response time, and service cost, etc. Specifically, the elevator PSS concept including the module of energy-saving was found to help each elevator to save about $10,800 \mathrm{~kW} \cdot \mathrm{h}$ every year and thereby contribute to decrease the environmental impact (see Table 10). In Table 10, total response time per PSS refers to the sum of service module instance's response time (see Table 9) in PSS. The expected lifecycle service cost of elevator in Table 10 refers to the sum of selected module instance's cost (see Table 9) in PSS configuration, and it includes knowledge support cost, purchase consulting cost, installation and commissioning cost, and customer care cost, etc. The power saving rate is about $30 \%$, and the average power consumption of each elevator per month is about $3,000 \mathrm{~kW} \cdot \mathrm{h}$. 
Table 10.

Comparisons between previous elevator PSS design and PSS design under the framework.

\begin{tabular}{|c|c|c|}
\hline Dimension of comparison & $\begin{array}{c}\text { Design before } \\
\text { implementing the } \\
\text { proposed framework }\end{array}$ & $\begin{array}{l}\text { Design after implementing } \\
\text { the proposed framework }\end{array}$ \\
\hline Requirement identification & $\begin{array}{l}\text { Focus on requirements of } \\
\text { enhancing elevator } \\
\text { performance }\end{array}$ & $\begin{array}{l}\text { Focus on requirements in } \\
\text { elevator lifecycle use }\end{array}$ \\
\hline $\begin{array}{l}\text { Technical attributes conflicts in } \\
\text { early concept design phase }\end{array}$ & Never being considered & $\begin{array}{l}\text { Conflicts are identified and } \\
\text { resolved to reduce potential } \\
\text { defects in PSS delivery }\end{array}$ \\
\hline Elevator service offering & Standardized & Customized \\
\hline $\begin{array}{l}\text { Customer complaints ratio } \\
\text { (Number of complaints / total } \\
\text { number of transactions) }\end{array}$ & About $15 \%$ & About 8\% \\
\hline Elevator service design reuse & Occasionally & Frequently \\
\hline $\begin{array}{l}\text { Backtracking of PSS failure } \\
\text { cause }\end{array}$ & $\begin{array}{l}\text { Tracing back the entire } \\
\text { service process takes long } \\
\text { time }\end{array}$ & $\begin{array}{l}\text { Easier to find the service } \\
\text { module with problem and } \\
\text { minimize potential losses }\end{array}$ \\
\hline Total response time per PSS $^{1}$ & About 43 hours & About 32 hours \\
\hline $\begin{array}{l}\text { Expected lifecycle service cost } \\
\text { of elevator }\end{array}$ & About RMB $¥ 240,000$ & About RMB $Y 180,000$ \\
\hline $\begin{array}{l}\text { Average power consumption of } \\
\text { an elevator per year }{ }^{3}\end{array}$ & About $36,000 \mathrm{~kW} \bullet \mathrm{h}$ & About $25,200 \mathrm{~kW} \cdot \mathrm{h}$ \\
\hline
\end{tabular}

Table 10 summarizes the comparison results from the interviews, which shows the PSS design framework is effective in elevator service offerings design. However, three designers and one senior manager considered that the framework implementation required some necessary computation steps in elevator service design, which is difficult for designers without such kinds of knowledge, and they suggested developing a computerized system to facilitate the whole PSS design process. The effectiveness and performance of the framework as shown in Table 10 was measured through semistructured interview, which involved interviewees' evaluation. Thus, developing a more transparent and systematic method for performance measurement with evaluation criteria is an interesting future work.

During the transformation to customized PSS provider, the company had a strong incentive to rethink its existing service operations and assess its capability to satisfy its customers. This was likely to result in certain improvement of PSS design processes and service operations. Basically, the proposed framework served as a steering tool that guided the PSS design team with essential decisions and actions (e.g. conflict identification and resolution). Besides, it facilitated frequent design reuse by encapsulating complex design knowledge into a module (Langlois, 2002). All the knowledge did not always need to be communicated beyond the boundary of a module, and thus the PSS design efficiency could be enhanced. The modularization in the framework could also facilitate the backtracking of PSS failure causes, because it was not needed to trace back every detail of the entire service process (see Table 10). 


\section{Discussion and conclusion}

\subsection{Discussion}

A major gap in literature addressed by this paper has been the lack of a systematic and comprehensive support for PSS customization. Through the case study, the proposed framework with specific design processes and methods has been found effective to fill in the gap.

Table 11 shows comparisons of the proposed framework with the former PSS design frameworks (the literature including frameworks in Table 2). " $\sqrt{ }$ " in Table 11 denotes that the framework has the key feature, "No" denotes that the framework does not have the key feature, and "P" denotes that the framework partially has the key feature. No previous framework has comprehensive coverage as the proposed one. The proposed framework provides end-to-end process for PSS customization from requirement identification to requirement fulfillment by configured PSS solutions based on modules, which has not been considered in previous framework. With a widened scope, the proposed framework's major differences as compared with existing life cycle design methods, which are reported by review articles such as (Ramani et al., 2010, Umeda et al., 2012), or general design methods exist in its orientation to customization and PSS. Specifically, differently with the other frameworks in Table 11, the proposed framework identifies requirements from the perspective of the customer's activity using product as well as facilitates conflict resolving and modularization. Especially, the framework by Pezzotta et al. (2013) and that by Lee et al. (2010) lack mechanisms of conflict resolving and modularization. Although the framework by Aurich et al. (2006) provides perspective of modularization and configuration for PSS design, it does not use the information of customer activity in requirement identification process. The technical attributes' conflicts resolving is also beyond the framework of Aurich et al. (2006). The framework of Kindström and Kowalkowski (2009) is based on multiple case study, but it lacks specific design process and methodical supports from requirements identification to PSS configuration.

Table 11.

Comparisons with former frameworks.

\begin{tabular}{|lccccc|}
\hline $\begin{array}{c}\text { Key features of } \\
\text { framework }\end{array}$ & $\begin{array}{c}\text { The } \\
\text { proposed } \\
\text { framework }\end{array}$ & $\begin{array}{c}\text { Aurich } \text { et al. } \\
\mathbf{( 2 0 0 6 )}\end{array}$ & $\begin{array}{c}\text { Kindström and } \\
\text { Kowalkowski } \\
\text { (2009) }\end{array}$ & $\begin{array}{c}\text { Pezzotta } \\
\text { et al. } \\
\text { (2013) }\end{array}$ & $\begin{array}{c}\text { Lee } \text { et } \\
\text { al. } \\
\text { (2010) }\end{array}$ \\
\hline $\begin{array}{l}\text { I-CAC-based } \\
\text { requirements } \\
\text { identification }\end{array}$ & $\sqrt{ }$ & No & $\mathrm{P}$ & $\mathrm{P}$ & $\sqrt{ }$ \\
\hline Conflict resolving & $\sqrt{ }$ & $\mathrm{No}$ & $\mathrm{No}$ & $\mathrm{No}$ & No \\
\hline Modularization & $\sqrt{ }$ & $\sqrt{ }$ & $\mathrm{No}$ & $\mathrm{No}$ & No \\
\hline $\begin{array}{l}\text { Configuration for } \\
\text { customization }\end{array}$ & $\sqrt{ }$ & $\sqrt{ }$ & $\mathrm{No}$ & $\mathrm{P}$ & No \\
\hline $\begin{array}{l}\text { End-to-end } \\
\text { process }\end{array}$ & $\sqrt{ }$ & $\mathrm{P}$ & No & $\mathrm{P}$ & $\mathrm{P}$ \\
\hline Case/example & Elevator & $\begin{array}{c}\text { Heavy road } \\
\text { construction } \\
\text { machine }\end{array}$ & $\begin{array}{c}\text { Multiple case } \\
\text { study (10 } \\
\text { companies })\end{array}$ & $\begin{array}{c}\text { Truck } \\
\text { repair }\end{array}$ & $\begin{array}{c}\text { Clothes } \\
\text { TakeIN }\end{array}$ \\
\hline
\end{tabular}

In addition, the results of the case study with elevator PSS design show that the framework is applicable and effective in industry. The case study of elevator PSS design serves as an illustrative example of a design process, which helps to enhance 
understanding of PSS customization process and can serve as a foundation for further research in this area. In more details, the case study presented in Section 4 has shown the following advantages of the proposed framework.

(1) The framework provides a systematic PSS design process, as well as its associated quantitative methods to reduce the randomness in PSS conceptual design process. Furthermore, the framework contains throughput mechanism so that the output from one phase provides input to one or more of the following phases. E.g., PSS requirement identification and analysis provide critical inputs for PSS configuration. Thus, it can systematically provide designers with standardized design process reference from the beginning requirements identification to the later concept configuration. Collectively, the framework facilitates modular design of customized solutions, and it provides systematic design supports from the requirement identification to the PSS concept configuration. As summarized in Table 10, the framework was found to generate positive effects including environmental one (e.g., the power saving rate is about $30 \%$ in Table 10).

(2) The framework involves conflict resolving in the early PSS design. Manipulating the potential design attributes' conflicts helps to reduce possible defects in subsequent process of detailed design and delivery. This is especially relevant in taking into account the environmental requirements or requirements from various lifecycle phases, as it makes more likely for conflicts to occur. Besides, conflict resolving in early design phase reduces possible defects and ensures to satisfy requirements. Table 10 shows that customer complaint ratio has been reduced from $15 \%$ to $8 \%$. As opposed to other articles dealing with conflicts in physical products (e.g., Chang and Chen, 2004), the proposed framework is innovative by addressing service aspects.

(3) Modular design thinking is introduced into the PSS customization framework. Table 10 shows that modularization in the framework facilitated frequent design reuse. This is also relevant in addressing products with multiple lifecycles (see e.g., Hatcher et al.,2011), as it needs to reuse design information for efficient lifecycle engineering. Table 10 also shows that the framework made it easier to trace back a failure, and thus enhances service design efficiency. The modularization feature also helped to make modifications to a specific existing PSS module by dealing with requirement changes without undermining the overall PSS structure. For example, to solve conflicts between TA9 (Coverage of service network) and TA10 (Time of service dispatching), a precise dispatching solution based on GIS (Geographic Information System) was proposed. In the modularization process, the previous component of "manual entry of geoinformation reported by user" was then replaced by the component of "automatic positioning based on GIS" without substantially redesigning the module of service dispatching.

(4) The synergy between the different methods and techniques under the framework is also a motivation to develop the framework as explained in Section 1, and has been shown in the case study. For instance, the HoQ has strength in identifying the negative relationships (conflicts) between TAs (e.g., conflict between TA9 and TA10), while TRIZ has advantages in conflict resolving due to its knowledge-based nature. The recommended inventive principle 10 (Preliminary action) in TRIZ was shown to be effective to resolve the conflict between TA9 and TA10. This shows clear benefits of a comprehensive framework as compared with a mere set of individual methods.

(5) The module-based PSS configuration in the framework can help the service provider to achieve flexible and optimized customization. After configuration optimization, total response time was reduced to 32 hours, and the expected lifecycle service cost was reduced to RMB $¥ 180,000$ (see Table 10). Besides, conflict resolving 
before PSS configuration can reduce conflicting goals in setting configuration optimization objectives, which will largely alleviate burden of solving multi-objective PSS configuration model. This also reflects the synergy between the different design stages of the framework.

\subsection{Conclusion}

This research has searched and examined existing literature on PSS customization systematically, and found needs of a systematic and comprehensive support for customization of PSS. Thus, a design framework with a design process is proposed using different methods. The proposed framework is then applied to customized design of elevator PSS by a leading company in industry. The results of elevator PSS design show that the framework is applicable and effective for enhancing various aspects of PSS including environmental one.

Although the proposed framework demonstrates potentials in PSS design, it still has more research to be conducted in the future. The current framework reacts to dynamic change of customer requirements, which leads to hysteretic customization results. Therefore, to continue to meet customer requirements more promptly, it is effective to take forecast of customer requirements into account in the framework. In addition, some processes in the framework will benefit from more mathematical formulation (e.g., configuration optimization of PSS), which will in turn bring extra burden of usage on the designer. Therefore, it is suggested to develop computerized tool to support the design process in the framework to increase the efficiency for performing the design process. Besides, more testing work with e.g. different product types is effective to gain even higher validity of the framework.

\section{Acknowledgments}

The work described in this paper was supported by the grants from the National Natural Science Foundation of China (Grant No.71501006; No.71420107025); and the Fundamental Research Funds for the Central Universities(YWF-14-RSC-112, YWF15-JGXY-010). This research work is supported also in part by the Mistra REES (Resource Efficient and Effective Solutions) program funded by Mistra (The Swedish Foundation for Strategic Environmental Research). The authors wish to express their deep appreciation to the case company for its support with interviews. Besides, the authors thank Mr. Maokuan Zheng and Mr. Yongkun Zhu for their contribution in collecting data. The authors also would like to thank the editor and the anonymous reviewers for their helpful comments and suggestions on the drafts of this paper.

(The number of words is 9619)

\section{References}

Altshuller, G. S., Shulyak, L., and Rodman, S., 1999. The innovation algorithm: TRIZ, systematic innovation and technical creativity. Technical Innovation Center, Inc.

Aurich, J.C., Fuchs, C., and Wagenknecht, C., 2006. Life cycle oriented design of technical Product-Service Systems. J. Cleaner Prod.14 (17), 1480-1494.

Akasaka, F., Nemoto, Y., Kimita, K., and Shimomura, Y., 2012. Development of a knowledge-based design support system for Product-Service Systems. Comput. Ind. 63(4), 309-318.

Baines, T. S., Lightfoot, H. W., Evans, S., Neely, A., Greenough, R., Peppard, J., Roy, R., Shehab,E., Braganza, A., Tiwari,A., Alcock, J. R.,Angus, J. P.,Bastl, M.,Cousens, A.,Irving, P.,Johnson, M.,Kingston, J.,Lockett, H.,Martinez, V.,Michele, P.,Tranfield, 
D.,Walton, I. M., and Wilson, H., 2007. State-of-the-art in product-service systems, P. I. Mech. Eng. B-J. Eng. 221(10), 1543-1552.

Berkovich, M., Krcmar, H., and Leimeister J., 2011.Requirements Engineering for Product Service Systems-A State of the Art Analysis. Bus. Inform. Syst. Eng. 3(6), 369-380.

Beuren, F. H., Ferreira, M. G. G., and Miguel, P. A. C.,2013. Product-service systems: a literature review on integrated products and services. J. Cleaner Prod.47, 222-231.

Chang, H. and Chen, L., 2004. The conflict-problem-solving CAD software integrating TRIZ into eco-innovation. Adv. Eng. Softw.35, 553-566.

Deb, K., Pratap, A., Agarwal, S.,Meyarivan, T. A. M. T., 2002. A fast and elitist multiobjective genetic algorithm: NSGA-II. IEEE.T.Evolut.Comput. 6(2), 182-197.

Dong, M., \& Su, L.Y., 2011. Modeling a configuration system of product-service system based on ontology under mass customization. Adv. Sci. Lett. 4(6-7), 22562261.

Gershenson, J. K., Prasad, G. J., \& Zhang, Y. 2003. Product modularity: definitions and benefits. J.Eng.Design.14(3), 295-313.

Geum, Y., Lee, S., Kang, D., \& Park, Y.,2011. The customization framework for roadmapping product-service integration. Serv.Bus. 5(3), 213-236.

Geum, Y., \& Park, Y., 2011. Designing the sustainable product-service integration: a product-service blueprint approach. J. Clean. Prod. 19(14), 1601-1614.

Hauser, J. R., Clausing, D.,1988. The house of quality. Harv. Bus. Rev. 32 (5), 63-73.

Hara, T., Arai, T. and Shimomura, T., 2009. A method to analyse PSS from the viewpoints of function, service activity, and product behaviour. In: Proceedings of the CIRP IPS2 conference 2009, 1-2 April, Cranfield, UK, 180.

Hatcher, G.D.,Ijomah, W.L., and Windmill, J.F.C., 2011. Design for remanufacture: a literature review and future research needs. J. Clean. Prod. 19, 2004-2014.

Hu, S. J., Ko, J., Weyand, L., ElMaraghy, H. A., Lien, T. K., Koren, Y., Bley, H., Chryssolouris, G., Nasr, N., and Shpitalni, M., 2011.Assembly system design and operations for product variety. CIRP Ann.-Manuf.Techn. 60(2), 715-733.

Jiao, J., \& Tseng, M. M.2004. Customizability analysis in design for mass customization. Comput. Aided. Design. 36(8), 745-757.

Kindström, D., Kowalkowski, C., 2009. Development of industrial service offerings: a process framework. J.Serv. Manage. 20(2), 156-172.

Kuo, T. C., 2013. Mass customization and personalization software development: a case study eco-design product service system. J. Intelligent Manuf. 24(5), 1019-1031.

Langlois, R. N., 2002. Modularity in technology and organization. J. Econ. Behav. Org. 49(1), 19-37.

Lee, S. W., Maeng, J. W., Hong, Y. K., Park, H. J., \& Kim, Y. S.,2010. Product-Service System Design Processes and Cases. The Asian Conference on Design and Digital Engineering (ACDDE 2010), 2010.8, 126-129.

Manzini, E., 1999. Strategic design for sustainability: towards a new mix of products and services. In Environmentally Conscious Design and Inverse Manufacturing, 1999. Proceedings. EcoDesign'99: First International Symposium On (pp. 434-437). IEEE. 
Meier, H., Völker, O., Funke, B.,2011.Industrial product-service systems (IPS2). Int. J. Adv. Manuf. Technol. 52(9-12), 1175-1191.

Meier, H., Roy, R.,Seliger, G., 2010. Industrial product-service systems-IPS 2. CIRPAnn-Manuf.Techn.59(2), 607-627.

Morelli, N., 2003. Product-Service Systems, a PerspectiveShift for Designers: A Case Study: the Design of aTelecentre.Design. Stud. 24(1), 73-99.

Manzini, E., Vezzoli, C., 2003. A strategic design approach to develop sustainable product service systems: examples taken from the 'environmentally friendly innovation'Italian prize. J. Cleaner Prod.11(8), 851-857.

Mont, O. K., 2002. Clarifying the concept of product-service system. J. Cleaner Prod.10(3), 237-245.

Moon, S. K., Simpson, T. W., Shu, J., Kumara, S. R., 2009.Service representation for capturing and reusing design knowledge in product and service families using objectoriented concepts and an ontology. J. Eng. Des. 20(4), 413-431.

Myint, S., 2003.A framework of an intelligent quality function deployment (IQFD) for discrete assembly environment. Comput. Ind. Eng. 45(2), 269-283.

Nemoto, Y., Akasaka, F., Shimomura, Y.,2015. A framework for managing and utilizing product-service system design knowledge. Prod. Plan.Control.(ahead-of-print), 1-12.

Pezzotta, G., Pirola, F., Akasaka, F., Cavalieri, S., Shimomura, Y., Gaiardelli, P.,2013.May).A Service Engineering framework to design and configure ProductService Systems. In 11th IFAC Workshop on Intelligent Manufacturing Systems.

Ramani, K., Ramanujan, D., Bernstein, W. Z., Zhao, F., Sutherland, J., Handwerker, C., Choi,J.K., Kim, H., and Thurston, D. , 2010.Integrated Sustainable Life Cycle Design: A Review. J. Mech. Design. 1332(9), 0910041-09100415.

Roy, R., 2000. Sustainable product-service systems. Futures. 32(3), 289-299.

Saaty, T. L., 1988. What is the analytic hierarchy process? Springer Berlin Heidelberg,109-121.

Sakao, T., 2007. A QFD-centred design methodology for environmentally conscious product design. Int. J. Prod. Res.45(18-19), 4143-4162.

Sakao, T., Fargnoli M., 2010. Customization in Ecodesign: A Demand-side Approach Bringing New Opportunities? J. Ind. Ecol. 14(4), 529 - 532.

Sakao, T., Shimomura, Y., 2007. Service Engineering: A Novel Engineering Discipline for Producers to Increase Value Combining Service and Product. J. Cleaner Prod.15(6),590-604.

Sakao, T., Shimomura, Y., Comstock, M., and Sundin, E., 2007.A Method of Value Customization.J.Theo. Appl. Mech. Eng. 49(2), 99 - 108.

Song, W., Wu, Z., Li, X., Xu, Z., 2015.Modularizing product extension services: An approach based on modified service blueprint and fuzzy graph.Comput. Ind. Eng. 85, 186-195.

Song, W., Ming, X., Han, Y., 2014. Prioritising technical attributes in QFD under vague environment: a rough-grey relational analysis approach.Int. J. Prod. Res.52(18), 5528-5545.

Song, W., Ming, X., Han, Y., Wu, Z.,2013a. A rough set approach for evaluating vague customer requirement of industrial product-service system. Int. J. Prod. Res.51(22), 
6681-6701.

Song, W.,Chan, F. T., 2015. Multi-objective configuration optimization for productextension service. J. Manuf. Systems. 37, 113-125.

Song, W., Ming, X., Han, Y., Xu, Z., and Wu, Z., 2015. An integrative framework for innovation management of product-service system. Int. J. Prod. Res. 53(8), 22522268.

Song, W., Ming, X., and Wu, Z., 2013b. An integrated rough number-based approach to design concept evaluation under subjective environments. J. Eng. Design. 24(5), 320-341.

Song, W., and Sakao, T., 2016. Service conflict identification and resolution for design of product-service offerings. Comput. Ind. Eng. 98, 91-101.

Sundin, E., Lindahl, M., Comstock, M., Sakao, T., \& Shimomura, Y., 2009. Achieving mass customisation through servicification. Inter. J. Internet. Manuf. Serv. 2(1), 5675.

Tu, J. C., Huang, Y. C., Kuo, T. C., \& Lin, Y. H.,2013. Construction of customization development procedures in product service systems. J. Ind. Prod. Eng. 30(5), 303326.

Tukker, A., 2004. Eight types of product-service system: eight ways to sustainability? Experiences from SusProNet.Bus.Strategy.Environ.13(4), 246-260.

Tukker, A., 2015.Product services for a resource-efficient and circular economy - a review.J. Cleaner Prod.97, 76-91.

Ulaga, W. and Chacour S.,2001.Measuring Customer Perceived Value in Business Markets.Ind. Market.Manage. 30: 525-540.

Umeda, Y., Takata, S., Kimura, F., Tomiyama, T., Sutherland, J. W., Kara, S., Herrmann, C., Duflou, J. R., 2012. Toward integrated product and process life cycle planningAn environmental perspective, CIRP Ann. Manuf.Techno. 61(2), 681-702.

Uppenberg, K.,Strauss, H.2010. Innovation and productivity growth in the EU services sector. European Investment Bank.

Vandermerwe, S., and Rada, J., 1988. Servitization of business: adding value by adding services, Eur. Manage. J. 6(4), 314-324.

Vasantha, G. V. A., Roy R., Lelah A. and Brissaud D., 2012. A review of productservice systems design methodologies. J. Eng. Des. 23(9),635-659.

Wang, P. P., Ming, X. G., Li, D., Kong, F. B., Wang, L., Wu, Z. Y., 2011. Status review and research strategies on product-service systems.Int. J. Prod. Res. 49(22), 68636883.

Waeyenbergh, G., Pintelon, L., 2009. CIBOCOF: A framework for industrial maintenance concept development. Int. J. Prod. Econ.121(2), 633-640.

\section{Viate}

Wenyan Song has been assistant professor at School of Economics and Management, Beihang University, China since 2014. His main research interest is Design of ProductService Systems. He has published on International Journal of Production Research, Journal of Manufacturing Systems, Journal of Engineering Design, and Computer \& Industrial Engineering, etc. He previously worked on several research projects on 
development of Product-Service Systems.

Tomohiko Sakao has been professor at Department of Management and Engineering, Linköping University, Sweden since 2007. He has been a visiting researcher at the University of Tokyo and at Technical University of Berlin since 2002 and 2009, respectively. His research interests include Ecodesign (Environmentally Conscious Design) and Integrated Product Service Engineering. He has been Subject Editor for Ecodesign and Product-Service System in Journal of Cleaner Production since 2014. He has published on Journal of Cleaner Production, The Journal of Industrial Ecology, The International Journal of Life Cycle Assessment, and International Journal of Production Research, among others. 